\title{
KONTRIBUSI PENGALAMAN PRAKERIN TERHADAP MINAT BERWIRAUSAHA SISWA SMK PROGRAM STUDI KEAHLIAN TEKNIK BANGUNAN
}

\author{
Hasbi \\ Pendidikan Teknik Sipil dan Perencanaan, FT, UNY \\ E-mail: hasbisingkerru@uny.ac.id
}

\begin{abstract}
Entrepreneurship education in order to foster interest in entrepreneurship for vocational high school students is an important aspect in accustoming graduates who are able to create employment. Sample of this research was entire Vocational High School students of Architecture Engineering Courses in Malang who has carried out on-the job training as many as 108 students. Based on the analysis by looking at propensity scores showed that: students' entrepreneurship categorized as high contribution. From 108 respondents, 11 students or $10.26 \%$ categorized as very high contribution, 47 students or $43.52 \%$, categorized as high contribution, 28 students or $25.92 \%$, categorized as adequate contribution, and 22 students or $20.38 \%$ categorized as low contribution. Based on these results, it can be concluded that interest in entrepreneurship is influenced by experience of on-the-job-training which experience provides knowledge and experience, so as to accustom a student's interest in entrepreneurship.
\end{abstract}

Keywords: entrepreneurship interest, On-the-Job Training experience, vocational high school

\begin{abstract}
ABSTRAK
Penanaman kewirausahaan dalam menumbuhkan minat berwirausaha bagi siswa SMK merupakan aspek penting dalam menghasilkan lulusan yang mampu menciptakan lapangan kerja (berwirausaha). Sampel dalam penelitian ini adalah seluruh siswa SMK Paket Keahlian Teknik Gambar Bangunan di Malang yang telah melaksanakan Prakerin sebanyak 108 orang siswa. Berdasarkan hasil analisis dengan melihat kecenderungan skor yang diperoleh, minat berwirausaha siswa termasuk dalam kategori tinggi. Dari 108 orang responden, yang termasuk pada kategori sangat tinggi sebanyak 11 orang atau sekitar 10,26\%; kategori tinggi sebanyak 47 orang atau sekitar 43,52\%, kategori cukup sebanyak 28 orang atau sekitar 25,92\%, dan kategori kurang sebanyak 22 orang atau sekitar 20,38\%. Berdasarkan hasil penelitian tersebut, maka dapat disimpulkan bahwa Minat berwirausaha dipengaruhi oleh pengalaman prakerin dimana pengalaman memberikan pengetahuan dan pengalaman dalam bekerja, sehingga dapat membentuk minat siswa dalam berwirausaha.
\end{abstract}

Kata kunci: minat berwirausaha, pengalaman prakerin, sekolah menengah kejuruan

\section{PENDAHULUAN}

Sekolah Menengah Kejuruan (SMK) merupakan salah satu pendidikan formal dengan sistem pola pendidikan menumbuhkembangkan potensi sumber daya manusia melalui kegiatan pengajaran yang berorientasi dunia kerja dengan mengarahkan peserta didik agar menjadi lulusan yang siap terjun di dunia usaha ataupun industri. Tujuan SMK seperti yang tercantum dalam Undangundang Nomor 20 Tahun 2003 tentang Sistem Pendidikan Nasional, Pasal 15 menyatakan bahwa pendidikan kejuruan merupakan pendidikan menengah yang menyiapkan peserta didik terutama untuk bekerja dalam bidang tertentu. SMK sebagai salah satu pendidikan vokasi yang menghasilkan tenaga kerja juga harus memiliki keunggulan komparatif (comparative advantage) dan keunggulan kompetitif (competitive advantage).

Sesuai dengan tujuan SMK diatas maka dapat ditarik kesimpulan bahwa salah satu faktor penentu kesuksesan tujuan SMK adalah kesiapan kerja dari peserta didik. Usman (2016:1) mengungkapkan bahwa berdasarkan dengan arah kebijakan pembangunan pendidikan nasional Direktorat Pembinaan SMK menetapkan visinya yaitu "terselenggaranya layanan prima pendidikan menengah kejuruan untuk membentuk lulusan 
SMK yang berjiwa wirausaha, cerdas, siap kerja, kompetitif, dan memiliki jati diri bangsa, serta mampu mengembangkan keunggulan lokal dan dapat bersaing di pasar global".

Namun dari data diatas SMK belum berperan maksimal untuk mengentaskan pengangguran di negeri ini, dimana para lulusan SMK belum dapat bekerja memenuhi tuntutan industri yang diterapkan saat ini. Putriatama (2016:1) pada kenyataannya masih ada lulusan SMK yang menganggur. Salah satu faktor kurang terserapnya lulusan SMK di dunia kerja adalah siswa kurang siap memasuki dunia kerja yang disebabkan oleh kurangnya wawasan dunia kerja dan kurangnya keterampilan.

Riyanti (2003:67) mengungkap bahwa salah satu faktor yang mempengaruhi minat adalah pengalaman dan pendidikan. Pengalaman yang dimaksud adalah pengalaman siswa dalam melaksanakan praktik kerja industri. Pengalaman yang baik yang diterima siswa dalam melaksanakan praktik kerja industri akan mempengaruhi minat siswa untuk berwirausaha, karena dari pengalaman yang siswa peroleh akan menimbulkan penilaian, atau anggapan bahwa menjadi seorang wirausaha sangat mudah, memiliki banyak teman, keuntungan yang menjanjikan dan merupakan profesi yang disegani di masyarakat.

Berdasarkan beberapa uraian di atas, maka dilakukan penelitian tentang kontribusi pengalaman prakerin terhadap minat berwirausaha siswa SMK Program Studi Keahlian Teknik Bangunan dalam menghadapi perubahan tuntutan pasar kerja sehingga mampu melakukan pekerjaannya dengan sukses.

Winkel (2004:650) mengemukakan bahwa minat yaitu kecenderungan yang agak menetap pada seseorang untuk merasa tertarik pada suatu bidang tertentu dan merasa senang berkecimpung dalam berbagai kegiatan yang berkaitan dengan bidang itu. Sedangkan Kamisa dalam Khairani (2013: 136) mengemukakan bahwa minat merupakan kehendak, keinginan atau kesukaan. Keinginan atau kesukaan tersebut akan muncul melalui berbagai pengalaman yang dilakukan oleh orang tersebut.

Berdasarkan beberapa pendapat di atas, dapat disimpulkan bahwa minat adalah keinginan atau ketertarikan seseorang terhadap suatu aktivitas yang dilakukan secara menarik sehingga menimbulkan kesukaan terhadap aktifitas yang dilakukan tersebut.

Kasmir (2011:19) menyatakan bahwa wirausaha adalah orang yang berjiwa berani mengambil risiko untuk membuka usaha dalam berbagai kesempatan. Seorang wirausaha harus memiliki jiwa berani dalam mengambil risiko untuk membuka suatu usaha baru tanpa harus merasa takut dengan kondisi yang tidak pasti akan terjadi.

Faktor-faktor yang memberikan kontribusi terhadap proses berwirausaha adalah kondisi internal dan eksternal pelaku wirausaha. Faktor-faktor internal dan faktor-faktor eksternal ini meliputi aspek teknis dan apek manajerial dalam berwirausaha. Faktor-faktor internal ini dapat terbentuk sebagai akibat dari pertumbuhan, pengalaman sebelumnya, dan perkembangan pada diri wirausahawan. Faktor internal antara lain berasal dari motivasi dan bakat dari masing-masing wirausahawan. Sama halnya pada kondisi internal adalah kondisi eksternal yang ada di lingkungan wirausahawan. Beberapa faktor eksternal seperti, keluarga, pendidikan, lingkungan dan masyarakat akan mempengaruhi kesiapan, dalam berwirausaha.

Sama kompleksnya pada kondisi internal adalah kondisi eksternal yang ada di lingkungan wirausahawan. Beberapa faktor 
eksternal seperti, keluarga, pendidikan, lingkungan dan masyarakat akan mempengaruhi kesiapan, dalam berwirausaha. Faktor-faktor tersebut adalah:

a. Motivasi

Menurut Irianto (2005:53) motifasi adalah sesuatu yang menggerakkan atau mendorong seseorang atau kelompok orang untuk melakukan atau tidak melakukan sesuatu. Selain itu Hasibuan (2001:219) mengartikan motifasi sebagai pemberian daya penggerak yang menciptakan kegarahan kerja seseorang agar mau bekerja sama, bekerja efektif dan terintegrasi dengan segala daya upayanya untuk mencapai kepuasan.

Berdasarkan teori tersebut dapat disimpulkan bahwa motivasi adalah semua kekuatan yang memberi energy, daya, arah, dan dorongan untuk melakukan atau tidak melakukan kegiatan-kegiatan tertentu guna mencapai tujuan, baik pemenuhan kebutuhan atau pencapaian kepuasan.

b. Keluarga

Pola asuh orang tua sangatlah menentukan pembentukan semangat berwirausaha anak-anak mereka (terutama pada usia 2 tahun sampai 16 tahun) ada 3 bentuk pola asuh yakni otoriter, permisif, dan demikratik. Jika seseorang berasal dari keluarga yang berwirausaha maka sejak kecil akan memperoleh pengetahuan tentang wirausaha. Maka minat berwirausaha dapat timbul dari keluarga.

c. Pendidikan

Pendidikan dijalankan dengan penuh kesadaran, mempunyai tujuan, target, dan sasaran tertentu serta diberikan secara sistematis untuk mengembangkan potensi yang ada. Nugroho (2013:22) menyatakan bahwa satu-satunya perjuangan atau cara untuk mewujudkan manusia yang mempunyai moral, sikap, dan keterampilan wirausaha adalah dengan pendidikan. Dengan pendidikan, wawasan individu menjadi lebih percaya diri, bisa memilih dan mengambil keputusan yang tepat, meningkatkan kreativitas dan inovasi, membina moral, karakter, intelektual, serta peningkatan kualitas sumber daya manusia yang lain sehingga akhirnya mampu berdiri sendiri.

d. Lingkungan Masyarakat

Nugroho (2013:23) menyatakan bahwa lingkungan sekitar mempunyai peranan yang penting dalam perkembangan individu. Seseorang yang tumbuh di lingkungan pedagang secara relatif akan mempunyai kesempatan yang lebih besar untuk menjadi pedagang. Demikian pula individu lain yang tumbuh di lingkungan petani, nelayan, wirausaha, guru, dan sebagainya. Secara garis besar lingkungan dapat dibedakan menjadi dua, yakni lingkungan fisik dan lingkungan sosial.

Mc Clelland (dalam Suryana, 2006:62) mengemukakan bahwa kewirausahaan ditentukan oleh motif berprestasi, optimisme, sikap nilai, dan status kewirausahaan atau keberhasilan. Sedangkan menurut Soedjono dalam Suryana (2006:62), karena kemampuan afektif mencakup sikap, nilai, aspirasi perasaan, dan emosi yang semuanya sangat bergantung pada kondisi lingkungan yang ada, maka dimensi kemampuan afektif dan kemampuan kognitif merupakan bagian dari pendekatan kemampuan kewirausahaan. Jadi, kemampuan berwirausaha merupakan fungsi dari perilaku kewirausahaan dalam mengombinasikan kreativitas, inovasi, kerja keras, dan keberanian dalam menghadapi resiko untuk memperoleh peluang.

Suryana (2006:4), fungsi dan peran wirausaha dapat dilihat melalui dua pendekatan yaitu secara mikro dan makro. Secara mikro, wirausaha memiliki dua peran, yaitu sebagai penemu (innovator) dan perencana (planner). 
Secara makro, peran wirausaha adalah menciptakan kemakmuran, pemerataan kekayaan, dan kesempatan kerja yang berfungsi sebagai mesin pertumbuhan perekonomian suatu Negara.

Menurut Hantoro (2005: 23-30), ciriciri manusia wirausaha adalah:

1) Memiliki moral tinggi

Jika diperhatikan manusia yang mempunyai moral tinggi adalah manusia yang bertaqwa kepada Tuhan, memiliki kemerdekaan batin sehingga tidak mengalami banyak gangguan, kekhawatiran, serta tekanan-tekanan didalam jiwanya, memiliki rasa kasih sayang terhadap sesama manusia, loyal tehadap hukum, memiliki sifat keadilan

2) Memiliki sikap mental wirausaha

Orang yang memiliki sikap mental wirausaha setidak tidaknya memiliki kriteria sebagai berikut: (a) berkemauan keras dan pantang menyerah; (b) berkeyakinan kuat atas kekuatan pribadi yang harus didasari oleh pengenalan diri, kepercayaan diri dan pemahaman pada tujuan dan kebutuhan; (c) jujur dan bertanggung jawab, hal ini harus didasari oleh moral yang tinggi dan disiplin pada diri sendiri; (d) ketahanan fisik dan mental, yang didasari oleh kesehatan jasmani dan rohani, kesabaran, ketabahan, ketekunan dan keuletan untuk bekerja keras dan pemikiran yang konstruktif dan kreatif

3) Memiliki kepekaan terhadap lingkungan

Ada empat hal yang harus dimiliki agar seorang wirausaha dapat peka terhadap lingkungan, yaitu: (a) pengenalan terhadap arti, ciri-ciri, serta manfaat lingkungan; (b) rasa syukur atas segala yang diperoleh dan dimilikinya; (c) keinginan yang besar untuk menggali dan mendayagunakan sumbersumber ekonomi lingkungan setempat; (d) kepandaian untuk menghargai dan memanfaatkan waktu secara efektif.
4) Memiliki keterampilan wirausaha

Terdapat beberapa keterampilan yang harus dimiliki seorang wirausaha yaitu, keterampilan berfikir kreatif, keterampilan mengambil keputusan, keterampilan dalam kepemimpinan, keterampilan manajerial dan keterampilan bergaul.

Dari beberapa ciri di atas dapat diambil kesimpulan bahwa manusia wirausaha harus dapat menggabungkan ciri-ciri tersebut sehingga dalam usaha yang dibuatnya akan menjadi sukses dan bahkan dapat menciptakan sesuatu yang baru, menciptakan lapangan kerja sehingga dapat menyerap tenaga kerja.

Pengalaman menurut Yudantara (2006: 54) adalah akumulasi dari setiap kejadian dan penyikapan terhadap permasalahan yang dialami. Hamalik (2008: 29) menjelaskan bahwa pengalaman adalah sumber pengetahuan dan pengalaman diperoleh karena adanya interaksi antara individu dengan lingkungannya. Sehingga dapat disimpulkan bahwa pengalaman adalah sumber pengetahuan, keterampilan dan pengalaman yang diperoleh dari akibat perbuatan atau pekerjaan yang telah dilakukan sebelumnya selama jangka waktu tertentu disebabkan adanya interaksi antara individu dengan lingkungannya.

Praktik Kerja Industri (Prakerin) merupakan bagian dari pendidikan sistem ganda yang merupakan inovasi pendidikan SMK yang mama siswa melakukan magang di industri yang relevan dengan program keahliannya selama kurun waktu tertentu (Pardjono, 2011:3).

Djojonegoro dalam Susanto (2011:36) mengemukakan bahwa penyelenggaraan pendidikan dan pelatihan dengan pendekatan Pendidikan Sistem Ganda bertujuan: menghasilkan tenaga kerja yang memiliki keahlian profesional, yaitu tenaga kerja yang sesuai dengan tuntutan lapangan kerja; (2) 
memperkokoh hubungan keterkaitan dan kesepadanan (Link and Match) antara lembaga pendidikan dan pelatihan kejuruan dengan dunia kerja; (3) meningkatkan efisiensi penyelenggaraan pendidikan dan pelatihan tenaga kerja berkualitas profesional dengan memanfaatkan sumber daya pelatihan yang ada di dunia kerja; dan (4) memberi pengakuan dan penghargaan terhadap pengalaman kerja sebagai bagian dari proses pendidikan. Sehingga tujuan prakerin untuk meningkatkan mutu dari peserta didik itu sendiri sehingga mereka kompeten di bidangnya

Kegiatan prakerin diidentikkan sebagai kegiatan magang. Magang merupakan praktik yang diawasi secara pribadi, tidak ada jadwal tugas seragam yang dapat dirangsang untuk semua orang. Sebaliknya, kesempatamkesempatan belajar harus secara pribadi dirancang sehingga mereka mencakup banyak pengalaman keberhasilan, dan murid-murid memperoleh kedewasaan dan kecakapan (Leigh, 2007:141).

Manfaat prakerin bagi sekolah menurut Suparlan (2008: 88) adalah untuk mengatasi kekurangan sarana dan prasarana di sekolah, sedangkan bagi siswa manfaatnya antara lain yaitu: (a) memiliki keahlian dan pengelaman kerja yang dapat memudahkan untuk mencari pekerjaan; (b) meningkatkan rasa percaya diri bahwa teori yang didapatkan di sekolah merupakan dasar untuk melakukan praktik di perusahaan atau industri; (c) memperpendek masa transisi (lead time) dari sekolah ke dunia kerja.

Pendapat di atas menjelaskan tentang pentingnya prakerin bagi peserta didik, karena dengan prakerin peserta didik telah dibekali pengalaman di dunia kerja sehingga mereka tidak mengalami kesulitan dalam memasuki dunia kerja.
Oleh sebab itu prakerin akan membekali peserta didik terutama dalam hal aspek non teknis, berupa:

a) Kedisiplinan

Kedisiplinan merupakan tolak ukur dalam melakukan suatu penilaian terhadap seseorang, karena apabila seseorang memiliki kedisiplinan yang baik maka semua pekerjaan akan diselesaikan dengan baik.

b) Kerja sama

Mengerjakan pekerjaan dengan sesama teman dan mampu beradaptasi dengan lingkungan kerja. Karena dalam pelaksanaan prakerin peserta didik dituntut untuk selalu bekerja sama dengan siapa saja yang mereka temukan apalagi dalam menemukan suatu masalah dalam hal ini pekerjaan yang dibebankan pada individu.

c) Inisiatif

Melakukan suatu pekerjaan diperlukan inisiatif bagi para pekerja baik dalam hal memutuskan suatu kebijakan ataupun dalam pekerjaan-pekerjaan lain. Apabila suatu pekerjaan tidak dapat diselesaikan oleh siapa saja maka inisiatif akan timbul dari beberapa pihak dalam menyelesaikannnya. Oleh sebab itu inisiatif begitu berperan dalam suatu pekerjaan.

d) Tanggung jawab

Pelaksanaan prakerin melatih peserta didik untuk memiliki tanggung jawab terhadap apa saja yang akan diberikan padanya. Dengan tanggung jawab yang dimiliki oleh peserta didik maka akan memudahkan mereka dalam memasuki dunia kerja.

e) Sikap (kerajinan, keuletan, dan kejujuran)

Sikap yang dimaksud dalam hal ini berupa : 1) kerajinan, ada pepata mengatakan rajin pangkal kaya, pepata tersebut mengandung makna apabila seseorang rajin dalam melakukan apa 
saja dan dilakukan secara terus menerus maka hasil yang didapatkan akan memuaskan dan dapat dirasakan oleh diri sendiri. Hal tersebut membuat peserta didik dalam melaksanakan prakerin sudah ditanamkan kerajinan pada diri peserta didik di dunia kerja sehingga mereka kelak memasuki dunia kerja akan memiliki sifat positif; 2) keuletan, setiap individu dibutuhkan keuletan dalam melakukan apasaja karena keuletan membawa peserta didik lebih maju. Sebagai contoh terdapat tugas yang dibebankan kepadanya tanpa rasa bosan mereka akan pantang mundur/menyerah dengan apa yang dibebankan kepadanya; dan 3) kejujuran, merupakan nilai yang ditanamkan dari diri seseorang mulai ia lahir. Hal tersebut disebabkan, kejujuran merupakan faktor utama dalam suatu pekerjaan terutama di dunia jasa konstruksi.

\section{METODE}

Penelitian ini merupakan penelitian cross sectional ex-post facto dengan menggunakan pendekatan kuantitatif.

Populasi penelitian ini adalah siswa SMK Kompetensi Keahlian Teknik Gambar Bangunan (TGB) di Kota Malang yang telah melaksanakan praktik kerja industri, kelas XII. Adapun jumlah populasi sebanyak 138 siswa dan tersebar pada 3 SMK yaitu: (1) SMK Negeri 1 Singosari sebanyak 52 siswa; (2) SMK Negeri 6 Malang sebanyak 62 siswa; dan (3) SMK Nasional Malang sebanyak 24 siswa.

Tabel 1. Populasi Siswa SMK Kompetensi Keahlian Teknik Gambar Bangunan di Kota Malang

\begin{tabular}{llr}
\hline No. & Nama Sekolah & Jumlah \\
\hline 1. & SMK Negeri 1 Singosari & 52 siswa \\
& & \\
2. & SMK Negeri 6 Malang & 62 siswa \\
\hline
\end{tabular}

\begin{tabular}{cc}
\hline 3. SMK Nasional Malang & 24 siswa \\
\hline Jumlah & 138 siswa \\
\hline
\end{tabular}

Pengambilan sampel dalam penelitian ini menggunakan teknik proportional random sampling. Sampel di setiap sekolah diambil secara acak sesuai dengan jumlah/proporsi masing-masing sekolah. Apabila populasinya kurang dari 100, semua populasi dijadikan sebagai sampel sehingga menjadi penelitian populasi. Jika jumlah populasinya lebih dari 100, dapat diambil $10-15 \%$ atau $20-25 \%$ atau lebih (Arikunto, 2002:112).

Tabel 2. Jumlah Sampel Siswa

\begin{tabular}{llcc}
\hline N & Nama Sekolah & $\begin{array}{c}\text { Jumlah } \\
\text { Populasi }\end{array}$ & $\begin{array}{c}\text { Jumlah } \\
\text { Sampel }\end{array}$ \\
\hline 1. & $\begin{array}{l}\text { SMK Negeri 1 } \\
\text { Singosari }\end{array}$ & 52 siswa & 38 siswa \\
& 62 siswa & 45 siswa \\
2. & $\begin{array}{l}\text { SMK Negeri 6 } \\
\text { Malang }\end{array}$ & 24 siswa & 17 siswa
\end{tabular}

3. SMK Nasional

Malang

\begin{tabular}{lc}
\hline Jumlah & 138 siswa \\
& siswa \\
\hline
\end{tabular}

Teknik pengumpulan data yang digunakan dalam penelitian ini menggunakan angket. Angket adalah daftar pertanyaan yang dibuat berdasarkan indikator-indikator dari variabel penelitian yang harus direspon oleh responden.

Berikut ini pembobotan dari alternatif jawaban angket dari setiap item

Tabel 3. Pembobotan/skor pada Setiap Jawaban

\begin{tabular}{ll}
\hline $\begin{array}{c}\text { Pertanyaan/pernyataan } \\
\text { Positif }\end{array}$ & Skor \\
\hline Sangat Baik/Sangat Setuju & 4 \\
\hline Baik/Setuju & 3 \\
\hline Cukup/kurang setuju & 2 \\
\hline
\end{tabular}




\begin{tabular}{ll}
\hline Kurang Baik/tidak setuju & 1 \\
\hline
\end{tabular}

Sumber: Djemari (2008: 49)

Uji Validitas Instrumen

Suatu instrumen dikatakan valid apabila dapat digunakan untuk mengukur data dari variabel yang diteliti. Validitas dalam penelitian ini dilakukan dengan menggunakan sampel uji coba sebanyak 30 orang siswa dari SMK Negeri 1 Singosari dan SMK Negeri 6 Malang, yang diambil dari luar anggota sampel penelitian sebesar 108 siswa dari dari SMK Negeri 1 Singosari, SMK Negeri 6 Malang dan SMK Nasional Malang.

Berdasarkan hasil analisis yang dilakukan untuk variabel minat berwirausaha, diketahui bahwa dari 24 butir pertanyaan yang diuji cobakan pada 30 siswa, ada 2 butir soal yang dinyatakan gugur (tidak valid) sebab nilai koefisien korelasinya lebih kecil dari $\mathrm{r}$ tabel pada taraf signifikansi $\alpha=0,05$. Dengan demikian, tersisa 22 butir pertanyaan yang dijadikan sebagai alat pengumpul data.

Sedangkan variabel pengalaman prakerin, diketahui bahwa dari 21 butir pertanyaan yang diuji cobakan pada 30 siswa, ada 2 butir soal yang dinyatakan gugur (tidak valid) sebab nilai koefisien korelasinya lebih kecil dari $\mathrm{r}$ tabel pada taraf signifikansi $\alpha=$ 0,05. Dengan demikian, tersisa 19 butir pertanyaan yang dijadikan sebagai alat pengumpul data.

Uji Reliabilitas Instrumen

Uji reliabilitas dilakukan untuk mengetahui sejauh mana dapat dipercaya.

Tabel 4. Hasil Uji Reliablitas Instrumen Penelitian

\begin{tabular}{lccc}
\hline Variabel & $\begin{array}{c}\text { Cronbach's } \\
\text { Alpha }\end{array}$ & $\begin{array}{c}\text { N of } \\
\text { Items }\end{array}$ & Keterangan \\
\hline Minat & .751 & 29 & Reliabel \\
\hline
\end{tabular}

\begin{tabular}{llll}
\hline Berwirausaha & & & \\
\hline $\begin{array}{l}\text { Pengalaman } \\
\text { Prakerin }\end{array}$ & .723 & 24 & Reliabel \\
\hline
\end{tabular}

Pada Tabel diatas diketahui bahwa untuk intrumen penelitian seluruh variabel telah memenuhi syarat untuk digunakan dalam pengumpulan data.

\section{HASIL DAN PEMBAHASAN}

Penelitian ini dilakukan di SMK Kota Malang, dengan subjek penelitian siswa Kelas XII Paket Keahlian Teknik Gambar Bangunan tahun ajaran 2014/2015 yang telah melaksanakan Prakerin. Data dalam penelitian ini dianalisis dengan menggunakan statistik deskriptif dan inferensial.

Uji Normalitas

Berdasarkan hasil pengujian yang dilakukan nilai signifikansi hasil hitungan SPSS masingmasing variabel lebih besar dari taraf signifikansi $(\alpha=0,05)$, Jadi dapat disimpulkan bahwa semua data varibel terdistribusi normal.

Uji Linearitas

Berdasarkan hasil pengujian yang dilakukan bahwa nilai signifikansi hasil masing-masing variabel lebih kecil dari taraf signifikansi ( $\alpha=$ 0,05), Jadi dapat disimpulkan bahwa kontribusi pengalaman prakerin terhadap minat berwirausaha siswa adalah linear.

\section{Uji Hipotesis}

Berdasarkan hasil analisis yang telah dilakukan maka ditemukan variabel pengalaman prakerin $\left(\mathrm{X}_{1}\right)$ diperoleh nilai konstanta $(\mathrm{a})=45,206$ dan nilai koefisien regresi $(b)=0,320$ dengan tingkat signifikansi $=0,001$. Maka persamaan garis regresi pengalaman prakerin terhadap minat berwirausaha siswa dapat dinyatakan dalam persamaan regresi sebagai berikut: 
$\mathrm{Y}=45,206+0,320 \mathrm{X}_{1}$

Persamaan tersebut menunjukkan bahwa nilai koefisien regresi bernilai positif sebesar 0,320, hal tersebut menjelaskan bahwa setiap kenaikan pengalaman prakerin (satu satuan), diprediksi tingkat minat berwirausaha siswa naik sebesar $0,320 \%$.

Sedangkan untuk hasil analisis koefisien korelasi variabel Pengalaman Prakerin $\left(\mathrm{X}_{1}\right)$ dengan minat berwirausaha $(\mathrm{Y})$ diperoleh nilai sebesar 0,309. Berdasarkan tabel interpretasi menurut Riduwan dan Sunarto (2011), hal tersebut menunjukkan bahwa tingkat hubungan variabel pengalaman prakerin $\left(\mathrm{X}_{1}\right)$ dengan minat berwirausaha (Y) berada dalam kategori rendah karena berada dalam interval koefisien antara 0,20 sampai 0,399

Besarnya kontribusi adalah kuadrat dari koefisien korelasi $\left(\mathrm{r}^{2}\right)$ diperoleh nilai kontribusi Variabel $\mathrm{X}_{1}$ terhadap Variabel $\mathrm{Y}\left(\mathrm{r}_{\mathrm{x} 1, \mathrm{y}}\right)$ sebesar 0,095 . Sehingga dapat dikatakan bahwa pengalaman prakerin berkontribusi sebesar 9,5\% terhadap kesiapan kerja siswa di bidang jasa konstruksi dan 90,5\% dipengaruhi oleh variabel lain.

Sedangkan untuk pengujian hipotesis yang telah dilakukan diperoleh nilai Sig. variabel pengalaman prakerin terhadap minat berwirausaha sebesar 0,000 . Nilai probabilitas $(0,05)$ lebih besar dari nilai probabilitas Sig. [0,05 > Sig.], maka Ha diterima dan Ho ditolak. Jadi pengalaman prakerin memiliki kontribusi positif terhadap minat berwirausaha siswa.

Minat berwirausaha siswa dapat ditingkatkan dengan berbagai cara, salah satu diantaranya melalui pelaksanaan prakerin. Dengan kegiatan prakerin, siswa dapat mengembangkan kemampuan, keahlian, dan profesi ditempat kerja sesuai dengan bidang studi atau jurusan masing-masing. Riyanti (2003) menyatakan bahwa faktor-faktor yang mempengaruhi minat adalah pengalaman dan pendidikan. Pengalaman yang dimaksud dalam adalah pengalaman siswa dalam melaksanakan praktik kerja industri.

Berdasarkan hasil analisis data dari penelitian yang telah dilakukan secara parsial antara pengalaman prakerin terhadap minat berwirausaha, diketahui terdapat korelasi yang positif dari kedua variabel tersebut. Artinya, semakin tinggi pengalaman prakerin siswa maka ada kecenderungan tingkat minat berwirausaha akan meningkat. Hal tersebut terjadi karena adanya pengalaman, dimana Vardiansyah (2008) dalam teorinya mengemukakan bahwa pengalaman memungkinkan seseorang menjadi tahu dan hasil tahu ini kemudian disebut pengetahuan.

Yoesoef dalam (Purwanto, 2002) juga mengemukakan bahwa untuk membentuk minat kewirausahaan dimulai dengan tahapan pemahaman teori, studi kasus, dan pemberian motivasi, ketiga tahap ini dapat dilakukan di sekolah, sedangkan tahap keempat adalah dengan magang (Prakerin).

Pendapat tersebut sesuai dengan hasil analisis yang diperoleh, yaitu pada indikator kerjasama, diperoleh nilai rata-rata paling tinggi yaitu sebesar $3,52 \%$. Hal tersebut disebabkan karena siswa memiliki rasa tanggung jawab terhadap harapan akan masa depan yang diimpikan dan percaya diri sehingga mampu beradaptasi beradaptasi dengan lingkungan kerja. Karena dalam pelaksanaan prakerin peserta didik dituntut untuk selalu bekerja sama dengan siapa saja yang mereka temukan apalagi dalam menemukan suatu masalah dalam hal ini pekerjaan yang dibebankan pada individu.

Hal tersebut didukungi oleh beberapa hasil penelitian yang telah dilakukan sebelumnya dimana salah satunya adalah penelitian yang dilakukan oleh Rahmi (2013) yang menyatakan bahwa ada pengaruh yang signifikan antara prakerin dengan minat 
berwirausaha. Penelitian yang sama juga dilakukan oleh Setyawan (2013) yang mengungkap bahwa terdapat hubungan antara praktik kerja industri terhadap minat berwirausaha. Pengetahuan, keterampilan, pengalaman kerja industri serta kemampuan kerja yang dimiliki oleh siswa dapat mendorong tumbuhnya minat berwirausaha.

Sejalan dengan hasil penelitian yang dilakukan, Suparlan (2008) menyatakan dalam teorinya bahwa manfaat prakerin bagi siswa antara lain yaitu: (a) memiliki keahlian dan pengalaman kerja yang dapat memudahkan untuk mencari pekerjaan; (b) meningkatkan rasa percaya diri bahwa teori yang didapatkan di sekolah merupakan dasar untuk melakukan praktik di perusahaan atau industri; (c) memperpendek masa transisi (lead time) dari sekolah ke dunia kerja. Pendapat tersebut menjelaskan tentang pentingnya prakerin bagi peserta didik, karena dengan prakerin peserta didik telah dibekali pengalaman di dunia kerja sehingga mereka tidak mengalami kesulitan dalam memasuki dunia kerja. Oleh sebab itu prakerin akan membekali peserta didik terutama dalam hal aspek non teknis, salah satunya adalah kerja sama, dimana peserta didik mengerjakan pekerjaan dengan sesama teman dan mampu beradaptasi dengan lingkungan kerja. Karena dalam pelaksanaan prakerin peserta didik dituntut untuk selalu bekerja sama dengan siapa saja yang mereka temukan apalagi dalam menemukan suatu masalah dalam hal ini pekerjaan yang dibebankan pada individu.

Putra (2009) dalam penelitiannya menegaskan bahwa pengalaman yang diperoleh pada saat melakukan praktik kerja industri secara tidak langsung akan mempercepat transisi siswa dari sekolah ke dunia industri, selain mempelajari cara mendapatkan pekerjaan juga belajar bagaimana memiliki pekerjaan yang relevan dengan bakat dan minat. Karena bakat dan minat akan mendorong individu untuk memusatkan perhatian dan meningkatkan aktivitas mental dan kegiatan yang sesuai dengan minatnya. Pengalaman dalam hal ini yaitu pengalaman yang didapat setelah melaksanakan praktik kerja industri, pengalaman kerja inilah yang akan menentukan minat siswa untuk berwirausaha karena di dalam industri siswa diajarkan untuk bekerja dengan kemampuan sendiri sehingga mereka akan mandiri.

Pengalaman merupakan pengetahuan atau keterampilan yang diketahui dan dikuasai oleh seseorang sebagai akibat dari pekerjaan yang telah dilakukan sebelumnya selama jangka waktu tertentu. Sehingga pengalaman prakerin dalam hal ini berperan dalam membentuk minat berwirausaha siswa. Setelah melaksanakan prakerin, siswa akan mengenal dan mengetahui kondisi nyata di dunia kerja, serta akan menambah pengalaman. Siswa tidak hanya mengerti tentang teori tetapi juga pengetahuan yang bersifat praktis. Ketika siswa melaksanakan prakerin di industri, keterampilan praktiknya akan lebih terlatih sehingga dapat meningkatkan kompetensinya baik secara kognitif, afektif maupun psikomotor. Jadi dapat dikatakan bahwa pengalaman prakerin mempunyai peran penting dalam mendukung minat berwirausaha siswa.

\section{SIMPULAN}

Pengalaman prakerin memberikan kontribusi yang signifikan terhadap minat berwirausaha siswa. Apabila pengalaman prakerin yang dimiliki oleh siswa semakin tinggi, maka diprediksi minat berwirausaha siswa akan semakin tinggi pula. Pengalaman prakerin memberikan kontribusi sebesar 37,2\% terhadap kesiapan kerja siswa di bidang jasa 
konstruksi, sedangkan $62,8 \%$ dipengaruhi oleh variabel lain.

\section{DAFTAR RUJUKAN}

Usman, H. 2013. Kinerja Guru SMK program keahlian teknik Bangunan di Daerah Istimewa Yogyakarta. Jurnal Pendidikan Vokasi. 3 (3).

Riyanti, D. 2003. Kewirausahaan dari Sudut Pandang Psikologi Kepribadian. Jakarta: Grasindo.

Winkel, W.S. 2004. Bimbingan dan Konseling di Institusi Pendidikan. Yogyakarta: Media Abadi.

Khairani, M. 2013. Psikologi Pembelajaran. Yogyakarta: Aswaja Persindo

Kasmir. 2011. Kewirausahaan. Jakarta: PT. Raja Grafindo Persada

Pardjono. 2011. Peran Industri dalam Pengembangan SMK. (Online), (http:// staff.uny.ac.id/ system/ files/ pengabdian/ prof-drs- pardjono-msc-phd/ peran-dudiutk-smk.docx), diakses 15 Desember 2013.

Leigh, R.W. 2007. Melayani dengan Efektif. Jakarta: Gunung Mulia

Suryana. 2006. Kewirausahaan Edisi 3. Jakarta: Salemba Empat.

Yudantara, I.K.G. 2006. Mengubah Ketidakpastian Menjadi Kekuatan. Jakarta: PT Elex Media Komputindo

Hamalik, O. 2011. Proses Belajar Mengajar. Jakarta: PT Bumi Aksara. 